\title{
DEVELOPMENT AND FORMULATION OF MEAL REPLACEMENT BREAKFAST BAR- ON THE GO FOR SEDENTARY LIFE STYLED ADULTS IN
}

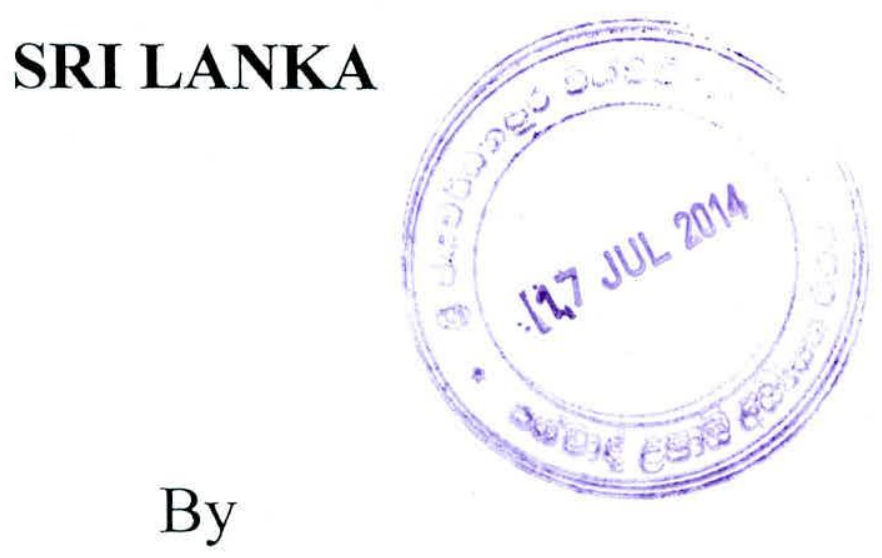

Weerakoon Mudiyanselage Sashi Dilum Weerakoon

This Thesis submitted in partial fulfillment of the requirements for the Degree of Masters of Food Science and Technology,

Department of Food Science and Technology,

Faculty of Applied Science,

University of Sri Jayewardenepura, Sri Lanka 


\section{DECLARATION}

The work described in this thesis was carried by me, under the supervision of Prof. Arthur Bamunuarachchiand the report on this thesis has not been submitted in whole or in part of any University or any other institution for another Degree/ Diploma.

$29 / 03 / 2014$

S.M.S. D. seerate

Date

W.M.S.D. Weerakoon 
"I certify that the above statement made by the candidate is true and that this thesis is suitable for submission to the university for the purpose of evaluation"

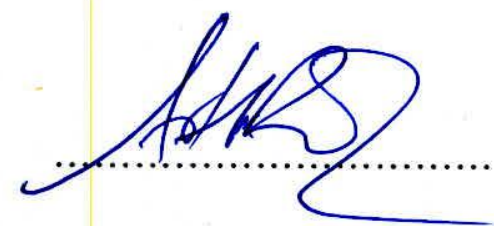

Prof. Arthur Bamunuarachchi,

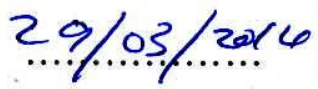

Date

Consultant Food Science and Technology,

Department of Food Scinece and Technology,

University of Sri Jayawardenepura,

Nugegoda,

Sri Lanka. 


\section{DEDICATED TOMY LOVING FAMILY MEMBERS}




\section{TABLE OF CONTENT}

DECLARATION

LIST OF CONTENTS IV

LIST OF TABLES XI

LIST OF FIGURES XIII

$\begin{array}{ll}\text { ACKNOWLEDGEMEN̦T XVI } & \text { XVTO }\end{array}$

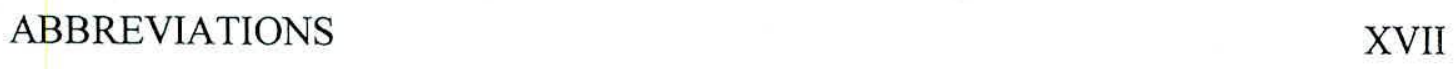

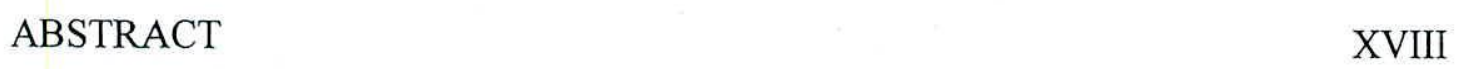

$\begin{array}{ll}\text { CHAPTER 1: INTRODUCTION } & 01\end{array}$

1.1 Meal Replacement Breakfast Bar on the go $\quad 01$

$\begin{array}{ll}\text { 1.1.1Problem Statement } & 02\end{array}$

$\begin{array}{ll}\text { 1.2.1 Justifications } & 02\end{array}$

$\begin{array}{ll}1.2 \text { Objectives } & 03\end{array}$

$\begin{array}{ll}\text { 1.2.1 General Objectives } & 03\end{array}$

$\begin{array}{ll}\text { 1.2.2 Specific Objectives } & 03\end{array}$

CHAPTER 2: LITERITURE REVIEW

2.1 Nutrition status and disease relationship of adults $\quad 04$

2.2 RDA and food base dietary guidelines for adults in Sri Lanka 06

2.3 Nutritional Assessment 11

2.3.1 Selecting the most appropriate method of collecting dietary data 13

$\begin{array}{ll}\text { 2.3.2 Nutrient calculation } & 13\end{array}$

$\begin{array}{ll}2.4 \text { Breakfast } & 14\end{array}$ 
2.6.1.1 Nutritional value

2.6.1.2 Health benefits

2.6.2 Cashewnuts

2.6.2.1 Nutritional Value

2.6.3 Textured Vegetable protein (TVP)

2.6.3.1 Nutritional value 22

2.6.3.2 Health benefits

2.6.4 Cowpea

2.6.4.1 Nutritional value

2.6.4.2 Health benefits

2.6.5 Chick Pea

2.6.5.1 Nutritional value 24

2.6.5.2 Health benefits 24

2.6.6 Sesame 25

2.6.6.1 Health Benefits 25

2.6.7 Coconut oil 26

2.6.7.1 Health benefits 26

2.6.8 Pop corn 26

2.6.8.1 Nutritional value 26

2.6.8.2 Health benefits 27 
2.6.9 Fruit cocktail

2.6.10 Mung Bean

2.6.10.1 Nutritional value

2.6.10.2 Health benefits

2.6.11 Papaya 28

2.6.11.1 Nutritional value 28

2.6.11.2 Health Benefits 28

2.6.12 Pineapple 28

2.6.12.1 Nutritional value 28

2.6.12.2 Health benefits 28

2.6.13 Mango 30

2.6.13.1 Nutritional value 30

2.6.13.2 Health benefits 31

2.6.14 Raisins

2.6.15 Coconut palm syrup 33

2.6.15.1 Nutritional value 33

2.6.15.2 Health benefits

2.6.16 Rice flakes

2.6.17 Puff rice 35

2.6.18 Liquid Glucose 35

2.6.19 Lecithin 35

2.6.20 Salt 35

2.7 Human nutrition 
3.1.5 Sample size calculation $\quad 43$

$\begin{array}{lll}3.1 .6 & \text { Nutrient calculation } & 44\end{array}$

3.2 Meal replacement breakfast bar formulation $\quad 44$

3.2.1 Raw materials 44

$\begin{array}{lll}3.2 .2 & \text { Equipments } & 45\end{array}$ 
3.2.3.1 Preparation of legumes $\quad 46$

3.2.3.2 Breakfast bar production $\quad 46$

3.2.3.4 Formulation $\quad 48$

3.2.4 Proximate analysis $\quad 49$

3.2.4.1 Determination of Moisture $\quad 49$

3.2.4.2 Determination of Total Carbohydrate $\quad 50$

3.2.4.3 Determination of Sugar $\quad 50$

3.2.4.4 Determination of Protein $\quad 52$

3.2.4.5Determination of Total fat $\quad 53$

3.2.4.6Determination of Total dietary Fiber 55

3.2.4.7Determination of Salt $\quad 56$

$\begin{array}{ll}\text { 3.3 Sensory evaluation } & 57\end{array}$

3.4 Shelf life studies analysis $\quad 58$

3.4.1 Physiochemical testing $\quad 58$

3.4.1.1 Determination of Moisture $\quad 58$

3.4.1.2 Determination of $\mathrm{PH} \quad 58$

$\begin{array}{ll}\text { 3.4.2 Total plate count } & 59\end{array}$

$\begin{array}{lll}3.4 .3 & \text { Coliform test } & 60\end{array}$

3.5 Cost Analysis $\quad 61$

CHAPTER 4: RESULTS AND DISCUSSION 63

4.1 Assessment of Nutrient intake in breakfast of sedentary adults 63

4.2 Meal replacement breakfast bar formulation $\quad 76$ 
4.2.1 Proximate analysis

$\begin{array}{lll}4.3 & \text { Sensory evaluation } & 82\end{array}$

4.3.1 Effect on color to select most preferred sample 82

4.3.2 Effect on flavor to select most preferred sample $\quad 82$

4.3.3 Effect on taste to select most preferred sample 83

4.3.4 Effect on texture to select most preferred sample $\quad 83$

4.3.5 Effect on overall acceptance to select most preferred sample $\quad 84$

$\begin{array}{ll}\text { 4.3.6 Shelf life evaluation } & 85\end{array}$

4.3.6.1 Physiochemical storage studies $\quad 85$

4.3.6.2 Microbial evaluation $\quad 86$

$\begin{array}{ll}4.4 \text { Cost Analysis } & 88\end{array}$

CHAPTER 5: CONCLUSION AND RECOMMENDATION 90

$\begin{array}{ll}5.1 \text { Conclusion } & 90\end{array}$

$\begin{array}{ll}5.2 \text { Recommendation } & 91\end{array}$

REFERENCE 92

$\begin{array}{ll}\text { APPENDIX I } & 97\end{array}$

$\begin{array}{ll}\text { APPENDIX II } & 98\end{array}$

$\begin{array}{ll}\text { APPENDIX III } & 102\end{array}$

$\begin{array}{ll}\text { APPENDIX IV } & 103\end{array}$

$\begin{array}{lr}\text { APPENDIX V } & 105\end{array}$

$\begin{array}{ll}\text { APPENDIX VI } & 106\end{array}$

$\begin{array}{ll}\text { APPENDIX VII } & 108\end{array}$

$\begin{array}{lr}\text { APPENDIX VIII } & 109\end{array}$ 


\section{LIST OF TABLES}

Table 2.1 Comparison of the average food intake of Sri Lankan adults with national and international recommendations

Table 2.2 Recommended dietary allowances for Sri Lankans 1998

Table 2.3 RDA for males and females aged 40-50 years in United Status (U.S.)

Table 2.4 Recommended number of serving sizes

Table 2.5 Summary of dietary assessment methods

Table 2.6 Nutritive Value in $100 \mathrm{~g}$ of Cashew Nut

Table 2.7 Nutrient content as per 172 grams of cowpeas

Table 2.8 Chemical composition of ripe papaya

Table 2.9 Nutrient level per $100 \mathrm{~g}$ of mango flesh

Table 2.10 Nutrient and potential benefit of raisins

Table 2.11 Simple classification of dietary constituents

Table 2.12 Average daily energy requirements of adults by category of occupational work expressed as a multiple of BMR

Table 3.1 Meal replacement breakfast bar formulations

Table 4.1 Main daily activities and time allocation of sedentary life styled population group

Table 4.2 Vitamin mineral fortification

Table 4.3 Proximate analysis of meal replacement breakfast bar on the go

Table 4.4 Nutritional labeling of meal replacement breakfast bar on the go 
Table 4.5 Effect on color to select most preferred sample

Table 4.6 Effect on flavor to select most preferred sample

Table 4.7 Effect on taste to select most preferred sample

Table 4.8 Effect on texture to select most preferred sample

Table 4.9 Effect on overall acceptance to select most preferred sample 


\section{LIST OF FIGURES}

Figure 3.1 Process flow diagram of meal replacement breakfast bar

Figure 4.1 No. of people vs energy intake

Figure 4.2 Details of mean energy intake

Figure 4.3 No of people vs carbohydrate intake

Figure 4.4 Details of carbohydrate intake 66

Figure 4.5 No of people vs protein intake 67

Figure 4.6 Details of protein intake 68

Figure 4.7 No of people vs total fat intake 68

Figure 4.8 Details of fat intake 69

Figure 4.9 No of people vs Calcium intake 69

Figure 4.10 Details of calcium intake 70

Figure 4.11 No of people vs iron intake 70

Figure 4.12 Details of iron intake 71

Figure 4.13 No of people vs Vitamin A intake 71

Figure 4.14 Details of vitamin A intake 72

Figure 4.15 No of people vs thiamin intake 72

Figure 4.16 Details of thiamin intake 73

Figure 4.17 No of people vs riboflavin intake 73

Figure 4.18 Details of riboflavin intake 74 
Figure 4.19 No of people vs niacin intake

Figure 4.20 Details of niacin intake

Figure 4.21 No of people vs vitamin C intake 75

Figure 4.22 Details of vitamin C intake 76

$\begin{array}{llr}\text { Figure 4.23 Meal replacement breakfast bar } & 80\end{array}$

Figure 4.24 Sensory attributes of different varieties of breakfast bars $\quad 85$

$\begin{array}{lll}\text { Figure 4.25 Moisture vs month } & 86\end{array}$

$\begin{array}{lll}\text { Figure 4.26 } & \mathrm{PH} \text { vs month } & 86\end{array}$

$\begin{array}{lll}\text { Figure } 4.27 & \text { Total plate count of bacteria vs month } & 87\end{array}$

$\begin{array}{lll}\text { Figure 4.28 } & \text { Yeast and mold count vs month } & 87\end{array}$

$\begin{array}{lll}\text { Figure 4.29 No of coliforms vs month } & 88\end{array}$ 


\section{ACKNOWLEDGEMENT}

I wish to express my sincere thanks and heart felt gratitude to my supervisor Prof. Arthur

Bamunuarachchi, Consultant Food Science and Technology of University of Sri Jayawardenepura.

Also I am thankful to Prof. K.K.D.S Ranaweera who given me the fullest support to complete this thesis.

I would like to give my special thanks to Ms. Kaushalya of Medical Research Institute, Colombo 08 for the special support given me to do this study.

I would like to thank Mr. Keppetigoda of National Institute of Education, Maharagama for the guidance and assistance given to me in several ways during the period of the survey.

I wish to express my sincere gratitude with deep appreciation to my husband, daughter and my parents for their encouragement given me to pursue this study. 


\section{ABBREVIATIONS}

TPC

Total Plate Count

SLS Sri Lanka Standard

App. Appendix

BMR Basal Metabolic Rate

TVP Textured Vegetable Protein

NCD Non Communicable Diseases

TAG TriAcylGlyceride

RNI Recommended Nutrient Intakes

RDA Recommended Dietary Allowances

WHO World Health Organization

GI Glycemic Index

CHD Coronary Heart Disease 


\begin{abstract}
Major health problems in Sri Lanka are associated with unhealthy dietary habits. The present study was conducted to develop a meal replacement breakfast bar on the go stored under refrigeration condition to provide balanced diet and convenience to the sedentary life styled adults in Sri Lanka who do not prepare their own food.

Preliminary nutri survey was conducted to asses breakfast consumption of hundred sedentary life styled adults selecting five organizations in Colombo district by using standard methods. Meal replacement breakfast bar was made withaggregation of $117^{\circ} \mathrm{C}$ heated syrup (Liquid glucose, crystal sugar, coconut oil, lecithin, salt, citric acid, fruit cocktail and water), mixture of cereals (puffed rice, rice flakes and popcorn), grains (roasted cowpeas, roasted mung beans, roasted chickpeas, roasted chana dhal and textured soya meat), nuts and seeds (peanuts, cashewnuts, sesame seeds), fruits (dried pineapple) and vitamin mineral premix to the proportion of 48:52syrup to the dry mixture, cooling, cutting to $50 \mathrm{~g}$ net weight of a bar. Packing was done in low density polyethylene wrappers. Proximate analysis was done to the formulated bar sample. Determination of most preferred variety was done with mango, papaya, pineapple and raisin bars. Shelf life evaluation and cost analysis was done to select the most preferred sample.

The results revealed that study population failed to achieve one third nutrients of RDA. Two $(100 \mathrm{~g})$ meal replacement breakfast bars should be consumed to get one third of nutrients in RDA. Meal replacement breakfast bar with pineapple is the most preferred sample. Moisture (4.3\%) and PH (5.75) did not effect to the product quality after three months of refrigeration storage. It is safe for consumption and it has $8.0 \times 10^{1}$ bacteria and no yeast, molds and coliforms were detected after three months of refrigeration storage. Retail price of a $50 \mathrm{~g}$ meal replacement breakfast bar with pineapple was valued at Rs.100.00 in the local market.
\end{abstract}

